Historic, Archive Document

Do not assume content reflects current scientific knowledge, policies, or practices. 

A99.9

E $76324^{\text {st Service }}$

$\cos 3.3$ per RM-76

Retie \#277\% 1971 (Revised 1972)

CUTTING IN

Rocky Mountain Forest and

Range Experiment Station

Forest Service

U.S. Department of Agriculture

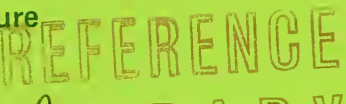

Fort Collins, Colorado

MuB $\mathrm{R}$ 漹

OLD-GROWTH

SPRUCE-FIR

by Robert R. Alexander

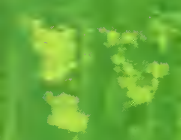




\section{Abstract \\ Interim guidelines are provided to aid the forest manager in developing alternatives to clearcutting in old-growth spruce-fir forests in Colorado and southern Wyoming. Included are partial cutting practices for different stand conditions and windfall and insect susceptibility that should maintain continuous high forest cover needed to preserve the forest landscape in recreation areas, travel influence zones, and scenic view areas. These partial cut- ting practices may also be used in combination with small cleared openings to create the form, structure, and arrangement of stands that appear desirable for increased water yields and improvement of wildlife habitat, and to integrate timber production with other key uses. \\ Key words: Forest cutting systems, Picea engelmannii, Abies lasiocarpa, windfall risk, multiple-use.}

Group selection cutting in spruce-fir on

the Fraser Experimental Forest. About half

the volume was removed from a third of the area

in group cuttings about one tree height in

diameter. Subsequent blowdown losses were light. 
USDA Forest Service

Research Paper RM-76
September 1971

Revised 1972

Initial Partial Cutting in 01d-Growth Spruce-Fir

by

Robert R. Alexander

Principal Silviculturist

Rocky Mountain Forest and Range Experiment Station ${ }^{1}$

${ }^{1}$ Central headquarters maintained in cooperation with Colorado State University at Fort Collins. 
Contents

Page

Partial Cutting History . . . . . . . . . . . . . 2

Susceptibility to Wind and Insects . . . . . . . . . . 3

Stand Conditions . . . . . . . . . . . . . . . . . . . . 4

Stand Descriptions . . . . . . . . . . . . . . . . . . 5

Single-storied stands . . . . . . . . . . . . . 5

Two-storied stands . . . . . . . . . . . . . . 6

Three-storied stands . . . . . . . . . . . . . . . . . . . 6

Multi-storied stands $. \quad . \quad . \quad . \quad . \quad . \quad . \quad . \quad . \quad . \quad 7$

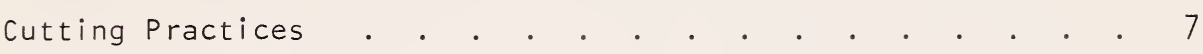

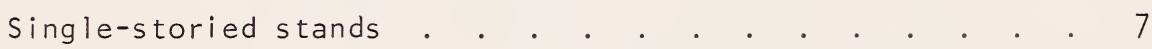

Two- and three-storied stands . . . . . . . . . . . . . .

Multi-storied stands . . . . . . . . . . . . . . . 9

Literature Cited . . . . . . . . . . . . . . . . . . 9 
For convenient field use, the stand descriptions and cutting guides in this Research Paper have been published separately in a smaller format ( $5 \frac{1}{2}$ by $8 \frac{1}{2}$ inches) as USDA Forest Service Research Paper RM-76A, "Initial Partial Cutting in $01 \mathrm{~d}-$ Growth Spruce-Fir--Field Guide to Stand Descriptions and Cutting Practices." Copies of RM-76A are available from the Rocky Mountain Forest and Range Experiment Station, 240 West Prospect Street, Fort Collins, Colorado 80521. 


\section{Individual tree selection cutting in spruce- fir on the Fraser Experimental Forest. About 60 percent of the volume was removed. Blowdown losses in the residual stand were heavy because the origi- nally dense stand was opened too drastically.}
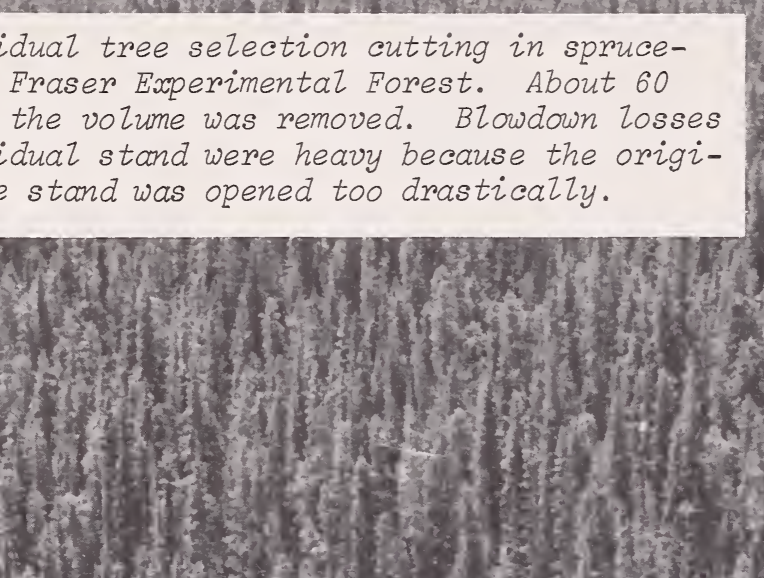

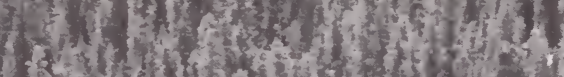

101,13

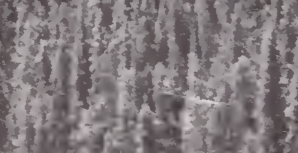

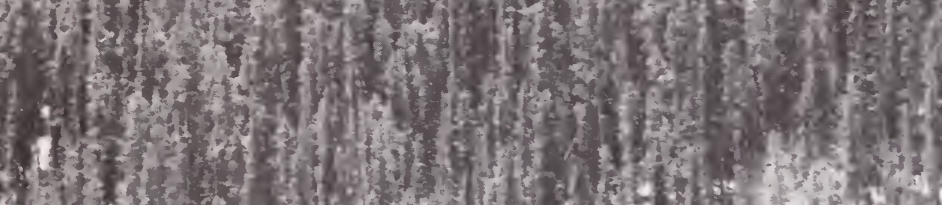

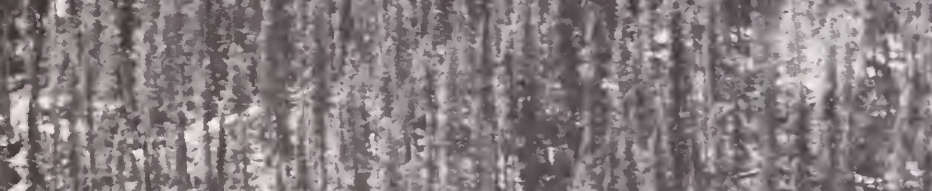

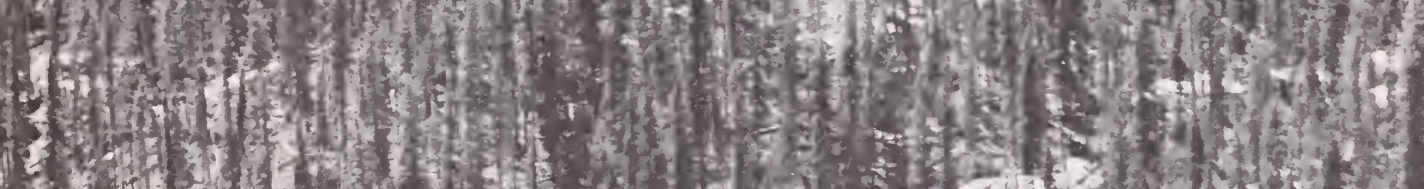

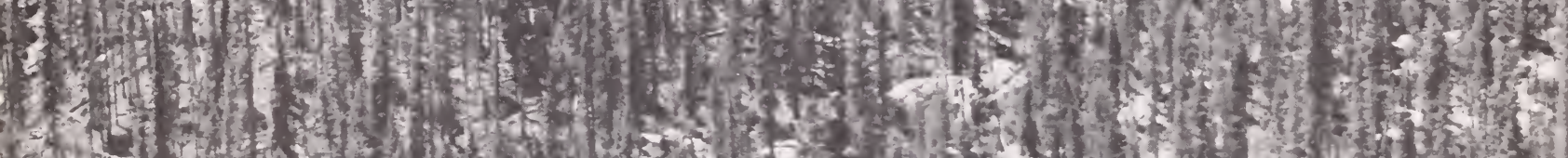

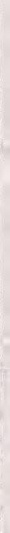

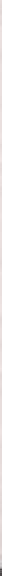




\title{
Initial Partial Cutting in Old-Growth Spruce-Fir
}

\author{
Robert R. Alexander
}

Harvesting and regeneration practices developed in the central Rocky Mountains have been directed toward converting virgin Engelmann spruce (Picea engelmannii Parry)-subalpine fir (Abies lasiocarpa (Hook.) Nutt.) forests to managed even-aged stands. ${ }^{2}$ This is sound procedure where timber production is the key use, because (1) many of these natural stands developed after fires or other disturbances and do not have an all-aged structure, and (2) a large proportion of these forests are in overmature stands that have limited potential for future growth.

In addition to being the most productive timber type in the central Rocky Mountains, these forests are also the highest water yielding, and valuable wildlife, recreation, and scenic areas. Because of increasing demands on forest lands from a rapidly expanding population and the limited resource available, managem ent must consider all key land uses. Changes in natural forest conditions associated with clearcutting for timber production-particularly where large openings are cut-may not be compatible with other objectives such as increased water yields, preservation of the forest landscape, maintenance of scenic values, and improvement of wildlife habitat. Silvicultural practices are needed that will establish and maintain healthy, vigorous, high forests with differing age-class structures.

The form, structure, and arrangement of stands that appear desirable for water production, wildlife habitat, and recreation and esthetics have been suggested in a general way from observations and research.

Water production studies have indicated that the increase in snow depth in openings

${ }^{2}$ Considerable literature is available on the silvical characteristics of spruce, and spruce regeneration requirements and practices for timber production, but that work will not be reviewed here. Good discussions are presented by Alexander (1958) and Roe et al. (1970). cut in spruce-fir forests is not additional snow but a change in deposition pattern (Hoover and Leaf 1967). Snow blows off adjacent standing trees and settles in the openings. The increase in water in the openings is, however, available for streamflow. Research and experience suggest that a round or patch-shaped opening, about five to eight times (in diameter) the height of surrounding trees, is the most effective for trapping snow. In larger openings, wind dips to the ground and scours and blows snow out of the opening. About one-third of the forest area should be in openings, which would be periodically recut when tree height reaches one-half the height of surrounding trees. The remaining two-thirds of the area would be retained as continuous high forest; trees would be periodically harvested on an individual tree or selection basis. Ultimately the reserve stand would approach an all-aged structure with the overstory canopy remaining at about the same height, although the original overstory could not be maintained indefinitely.

An alternative that would integrate water and timber production would harvest all of the old.growth in a cutting block in a series of cuts spread over a period of 120 to 160 years. Each cutting block would contain at least 300 acres, subdivided into round or patch-shaped units approximately 2 acres in size or four to five times (in diameter) the height of a general canopy level. At periodic intervals, some of these units, distributed over the cutting block, would be harvested and the openings regenerated. The interval between cuttings could vary from as often as every 10 years to as infrequently as every 30 to 40 years. The percentage of units cut at each interval would be determined by Cutting cycle/Rotation age $\mathrm{x}$ 100. At the end of one rotation, each cutting block would be composed of groups of trees in several age classes ranging from reproduction to trees ready for harvest. The height of the tallest trees would be somewhat shorter than the original overstory, but any adverse effect on snow deposition should be minimized by keeping the openings small and widely spaced. 
Big game use of spruce-fir forest lands can be improved by certain timber cutting practices, as shown in two recently completed studies. Openings of less than 20 acres cut in the canopy of spruce-fir forests in Arizona were heavily used by desert mule deer ( $\underline{O d o}_{-}$ coileus hemionus crooki Mearns) and American elk (Cervus canadensis canadensis (Erxleben) Reynolds), but use decreased considerably in larger openings (Reynolds 1966). Openings created by harvesting were preferred to natural openings because the vegetation that initially comes in on cutovers is more palatable to deer and elk. Reynolds suggested that openings be maintained by cleaning up the logging slash and debris, removing new tree reproduction, and seeding the area to forage species palatable to big game. However, since natural succession on the cutover areas is likely to eventually replace the more palatable species, a more desirable alternative would be to cut new openings periodically while allowing the older cuttings to regenerate. That would provide a constant source of palatable forage and the edge effect desired, while creating an all-aged forest by even-aged groups. The openings created should be widely spaced, with the stand between openings maintained as high forest.

On the Fraser Experimental Forest in Colorado, Rocky Mountain mule deer (Odocoileus hemionus hemionus Rafinesque) use in sprucefir forests was greater on 3-chain-wide clearcut strips than on wider or narrower strips (Wallmo 1969). While no recommendations were made as to optimum size or arrangement of openings, the Fraser study suggests that they be kept small and interspersed with standing trees that could be periodically harvested on an individual tree basis.

Wildlife other than big game is also influenced by the way forests are handled. For example, with the curtailment of wildfires, some reduction in stand density by logging is probably necessary to create or maintain drumming grounds for male blue grouse (Dendragapus obscurus Say). Partial cutting that opens up the canopy enough to allow tree regeneration to establish in scattered thickets appears to provide the most desirable habitat. Cutting small, irregularly shaped openings (up to 10 acres) in the canopy may also be beneficial to blue grouse, if thickets of new reproduction become established in the cleared openings (Martinka 1970).

In recreation areas, travel influence zones, and scenic view areas, permanent forest cover is preferred. Since old-growth spruce-fir stands may not maintain themselves in an esthetically pleasing or sound condition forever, some partial cutting system offers the best solution to the problem of maintaining permanent forest cover. From the recreational users' point of view, openings cut in stands for timber and water production, and wildlife habitat improvement-especially those that can be seen from distant views - should be kept small, resemble natural openings, and be interspersed with forest cover that shows little or no vegetative manipulation. Natural-looking shapes that blend into the landscape should be used instead of fixed geometric patterns (Barnes 1971).

\section{Partial Cutting History}

From about 1910 to the early 1950 's, cutting in spruce-fir on the National Forests was almost exclusively some type of partial cutting. Observations on those cuttings suggest some of the capabilities and limitations of existing stands to maintain permanent forest cover.

In general, heavy partial cutting-usually considered necessary to make logging profitable-was not successful as a means of arresting stand deterioration. For example, residual stands of spruce-fir in Colorado suffered heavy mortality when 60 percent or more of the original volume was removed by individual tree selection (Alexander 1963, U. S. Forest Service 1933). Similar results followed heavy partial cutting in the Northern Rockies (Roe and DeJarnette 1965). Even when mortality was not a problem, heavy partial cutting left the older, decadent stands in a shabby condition, with little appearance of permanent forest cover.

Windfall, the principal cause of mortality, increased as the intensity of cutting increased. Low stumpage values and the generally scattered pattern of windfall usually prevented salvage of blowdown after partial cutting. Not only was the volume of windthrown trees lost, but the combination of down spruce and overstory shade provided breeding grounds for spruce beetles (Dendroctonus rufipennis Kirby).

Partial cutting has been successful-in the sense that the residual stand did not suffer heavy mortality-in some spruce-fir stands where large reserve volumes were left in protected locations. In one study in northern Idaho, windfall losses were light after a partial cutting that left 6,000 board feet per acre in spruce-fir stands in a sheltered location on deep, well-drained soil (Roe and DeJarnette 1965). On the Grand Mesa National Forest in 
Colorado, where spruce trees are relatively short and there are no serious wind problems associated with topography, few trees blew down when about 40 percent of the original volume was removed from two-storied stands. In singlestoried stands, however, only about 30 percent of the original volume could be safely removed. On the other hand, heavier partial cutting that removed 50 percent or more of the original volumes per acre from spruce-fir forests in the dry "rain shadow" of the Continental Divide on the Rio Grande National Forest did not result in blowdown to the residual stand. However, these two-storied stands were growing on sites where productivity was very low. Individual trees were short, widely spaced, and therefore relatively windfirm before cutting.

There are also numerous examples of early cuttings-between 1910 and 1930-on many National Forests in Colorado where very light partial cutting-removal of 10 to 15 percent of the stand-did not result in substantial windthrow of residual trees.

Although an overstory tends to favor fir reproduction over spruce, regeneration success of spruce has been acceptable under a wide variety of partial cutting treatments (Alexander 1963, Roe and DeJarnette 1965).

\section{Susceptibility to Wind and Insects}

Windfall is a common cause of mortality after any kind of initial cutting in old-growth spruce forests, but partial cutting increases the risk because the entire stand is opened up and therefore vulnerable. While the tendency of spruce to windthrow is usually attributed to a shallow root system, the development of the root system varies with soil and stand conditions. On medium to deep, well-drained soils, trees have a better root system than on shallow, poorly-drained soils. Trees that have developed together in dense stands over long periods of time mutually protect each other, and do not have the roots, boles, or crowns to withstand sudden exposure to wind if opened up too drastically; and if the roots and boles are defective, the risk of windthrow is increased. The presence of old windfalls in a stand is another good indicator of lack of windfirmness. Furthermore, regardless of the kind or intensity of cutting, or soil and stand conditions, windthrow is greater on some exposures than others (Alexander 1964, 1967). Exposures where windfall risk is above and below average and very high have been identified as follows:

\section{Below Average}

1. Valley bottoms, except where parallel to the direction of prevailing winds, and flat areas.

2. All lower, and gentle middle north and east facing slopes.

3. All lower, and gentle middle, south and west facing slopes that are protected from the wind by considerably higher ground not far to windward.

\section{Above Average}

1. Valley bottoms parallel to the direction of prevailing winds.

2. Gentle middle south and west slopes not protected to the windward.

3. Moderate to steep middle, and all upper north and east facing slopes.

4. Moderate to steep middle, south and west facing slopes protected by considerably higher ground not far to windward.

Very High

1. Ridgetops

2. Saddles in ridges

3. Moderate to steep middle south and west facing slopes not protected to the windward.

4. All upper south and west facing slopes.

The risk of windfall in these situations is increased at least one category by such factors as poor drainage, shallow soils, defective roots and boles, and overly dense stands. Conversely the risk of windfall is reduced, if the stand is open-grown or composed of young, vigorous, sound trees. All situations become very high risk if exposed to special topographic situations such as gaps or saddles in ridges at higher elevations to the windward that can funnel winds into the area.

Spruce beetle is the most serious insect pest in mature to overmature Engelmann spruce, and epidemics have occurred throughout recorded history (Hopkins 1909, Massey and Wygant 1954). The most damaging outbreak was in Colorado from 1939-51, when the beetle killed nearly 4 billion board feet of standing spruce. Those attacks have been largely associated with extensive windthrow where down trees have provided an ample food supply needed for a rapid buildup of beetle populations (Massey and Wygant 1954, Wygant 1958). Cull material left after logging has also started outbreaks, and there are numerous examples of heavy spruce beetle populations developing in scattered trees windthrown after heavy partial cutting. The beetle progeny then emerged to 
attack living trees, seriously damaging the residual stand. Occasionally heavy spruce beetle outbreaks have developed in overmature stands with no recent history of cutting or windfall. Losses in uncut stands that have not been subjected to catastrophic windstorms, however, have usually been no greater than normal mortality in old growth.

Spruce beetles feed and breed in the phloem layer. The first evidence of attack is the red boring dust from entrance holes that usually accumulates in bark crevices on the boles and around the bases of infested trees. The needles of killed trees usually turn a yellowish green and fall about 1 year after attack, but they may remain green until the second year (Schmid and Beckwith 1971).

Overmature trees are usually attacked first, but if an infestation persists, beetles will attack and kill smaller diameter trees after the larger trees in the stand are killed. In the central Rocky Mountains, susceptibility of stands of spruce decreases in the following order: (1) trees in creek bottoms, (2) better stands on benches and high ridges, (3) poorer stands on benches and high ridges, (4) mixed stands, and (5) immature stands (Schmid and Beckwith 1971).

Natural factors such as nematodes, insect parasites and predators and woodpeckers normally maintain beetle populations at low levels, but generally fail to control populations under outbreak conditions. Extremely low temperature can however, eliminate beetle infestations if the insect has not developed cold-hardiness. Sudden low fall temperatures of $-15^{\circ} \mathrm{F}$. under the bark will kill nearly all adults, while $-30^{\circ}$ F. will kill the larvae (Schmid and Beckwith 1971). Chemical control is expensive and only a holding action until potentially susceptible trees can be disposed of otherwise. In infested stands, or those with potential beetle problems, felling and salvaging attacked or susceptible trees, and disposing of green cull material is the most effective silvicultural control. However, partial cutting that removes the larger overmature trees and releases the younger trees is another way to reduce potential insect problems in stands with a good stocking of trees in the smaller diameter classes. "Trap trees" intentionally felled prior to beetle flight, are highly attractive and often provide an effective way of concentrating and trapping spruce beetles. After the beetles enter the downed logs, they are usually salvaged, but may be chemically treated or burned (Schmid and Beckwith 1971).

\section{Stand Conditions}

The great diversity in stand conditions within the spruce-fir type complicates the modification of silvicultural systems for multiple use. For example, spruce-fir forests are the dominant elements in a number of near climax vegetation associations throughout much of the area they occupy, but they do not have the all-aged structure of true climax forests. Some stands are clearly single-storied, others are two- or three-storied, and multi-storied stands are not uncommon (LeBarron and Jemison 1953, Miller 1970). This structure is largely the result of either past disturbances such as fire, insect epidemics, or cutting, or the gradual deterioration of old-growth stands associated with normal mortality from insects, diseases, and wind. The latter circumstance is especially evident in the formation of multistoried stands.

The composition of old-growth forests is frequently nearly pure spruce in the overstory with fir predominating in the understory and advanced reproduction. In Colorado and Wyoming, for example, spruce commonly makes up from 70 to more than 90 percent of the overstory, and fir from two-thirds to four-fifths of the understory and advanced reproduction (Alexander 1957, 1963; Oosting and Reed 1952). This composition in relation to structure has developed under natural conditions because spruce becomes readily established only on mineral soil and rotten-wood seedbeds, whereas fir is not as exacting in its seedbed requirements. Furthermore, although spruce seedling survival is better in the shade than in the open, spruce cannot compete with fir under the low light intensities commonly associated with dense spruce-fir forests. Once established, on the other hand, spruce lives longer than fir (Alexander 1958).

Advanced reproduction is likely to be older than it appears because the early growth of both spruce and fir is very slow. Spruce commonly takes from 20 to 40 years to reach a height of 4 to 5 feet, even under favorable conditions, whereas under a dense canopy spruces 4 to 6 feet tall are frequently 75 or more years old (Oosting and Reed 1952). Spruce and fir reproduction suppressed for long periods will respond to release, however, and make acceptable growth.

Although spruce commonly grows with fir, other species including lodgepole pine (Pinus contorta Dougl.), aspen (Populus tremuloides Michx.), and Douglas-fir (Pseudotsuga menziesii var. glauca (Beissn.) Franco) grow with spruce in the middle to low elevational ranges. Local variations are often caused by aspect. In Colorado, south and west slopes up to 10,500 feet elevation especially favor the development of mixed spruce, fir, and lodgepole pine stands. 


\section{Stand Descriptions}

A classification based on stand characteristics is needed to (1) identify the kinds of stands that can be partially cut, those that must be clearcut and started new, and those that should be left uncut; and (2) develop partial cutting practices in spruce-fir forest for different management objectives. Until such a classification is available, the following broad stand descriptions, based largely on experience and observation, are suggested:

\section{A. Single-storied stands}

1. May appear to be even-aged, but usually contain more than one age class. In some instances, the canopy may not appear to be of a uniform height because of changes in topography, stand density, or stocking.

2. Codominant trees form the general level of the the overstory canopy. Dominants may be 5 to 10 feet taller, and occasional superdominants may reach 15 to 20 feet above the general canopy level.

\footnotetext{
${ }^{3}$ Reproduction less than 4.5 feet tall is not considered a stand story in these descriptions.
}

Taller intermediates extend into the general canopy; shorter intermediates are below the general canopy level but do not form a second story.

3. Small range in diameters and crown length of dominants and codominants.

4. Few coarse limbed trees in the stand; if two-aged or more, younger trees usually have finer branches and may not have diameters equal to the older trees.

5. Trees more often uniformly spaced than clumpy.

6. Usually does not have a manageable stand of advanced reproduction.

\footnotetext{
${ }^{4}$ Since any kind of cutting in spruce-fir forests may destroy as much as one-half of the advanced reproduction even with careful logging, at least 600 seedlings and saplings per acre of good form and vigor, and free of defect must be present to be considered a manageable stand (Roe et al. 1970). Needless destruction of a manageable stand of advanced reproduction because the composition is largeIy fir is not justified when one of the management objectives is to establish and maintain forest cover.
}

\section{SINGLE - STORY}

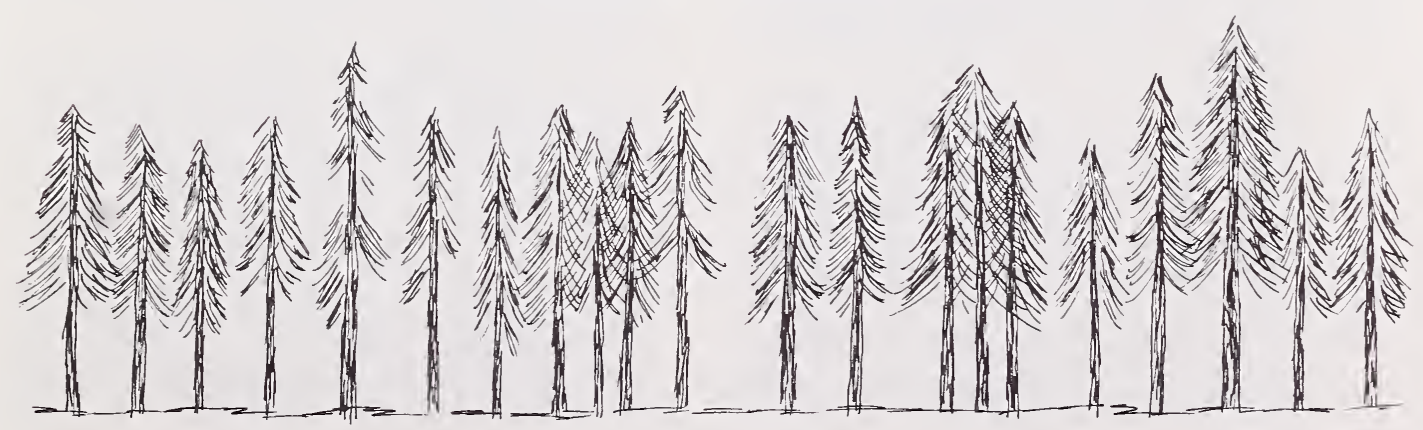




\section{TWO-STORY}
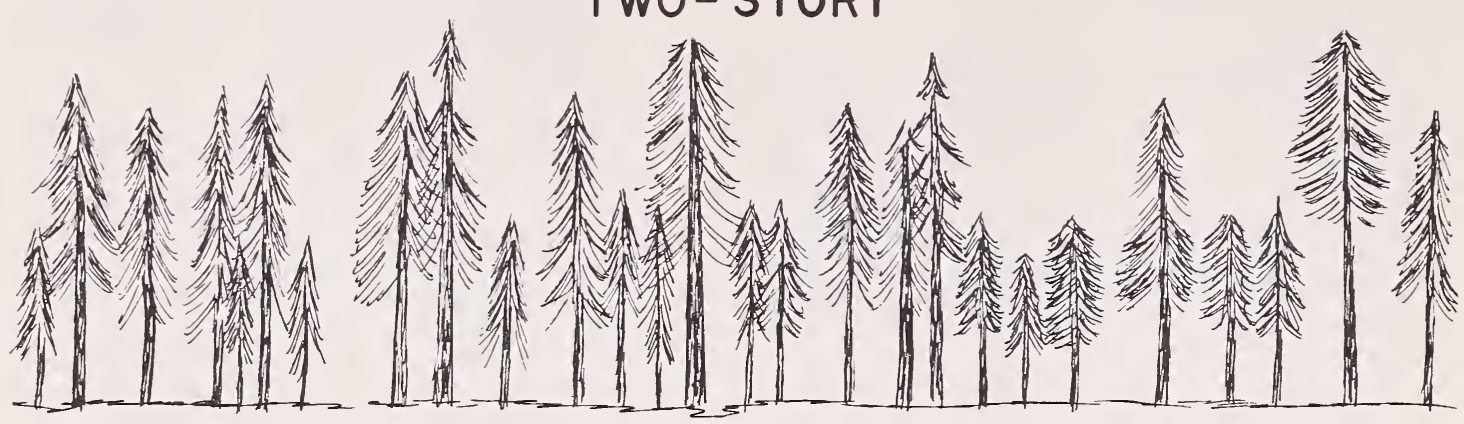

\section{THREE - STORY}

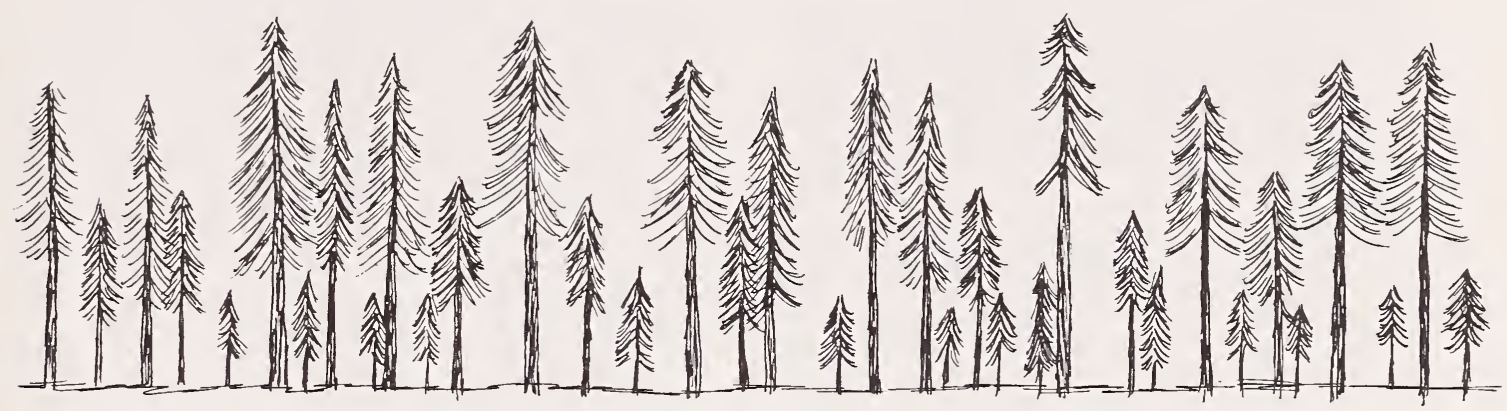

B. Two-storied stands

1. May appear to be two-aged, but usually contains more than two age classes.

2. Top story (dominants, codominants, and intermediates) is usually spruce; resembles a single-storied stand.

3. Second story is usually fir, younger trees of smaller diameter than the overstory. May consist of small saw logs, poles, or large saplings, but is always below the top story and clearly distinguishable from the overstory. Trees in the second story are overtopped, but not suppressed.

4. May contain a manageable stand of advanced reproduction.

5. Arrangement of individual trees varies from uniform to clumpy.
C. Three-storied stands

1. May appear to be three-aged, but usually contains more than three age classes. Occasionally two-aged, but is never all-aged.

2. If three-aged or more, top story usually predominantly spruce and resembles a single-storied stand except that there are fewer trees. Second and third stories consist of younger, smaller diameter trees (that is, small saw logs, poles, and large saplings) that are usually fir. In a typical stand, the second story will be 10 to 30 feet below the top story and consist of small saw logs or large poles. Third story will be 10 to 30 feet below the second story and consist of small poles or large 


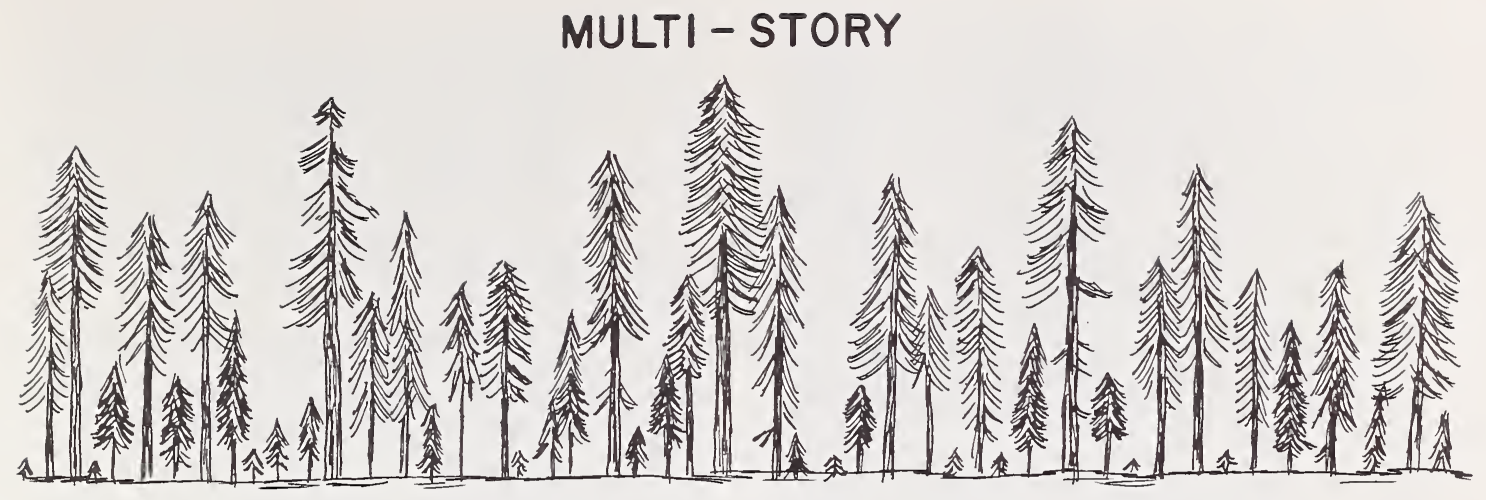

saplings. Although the second and third stories are overtopped, the trees are not suppressed.

3. If two-aged, first two stories are oldgrowth with spruce in the top story and fir in the second story. The third story will be younger trees, largely fir, of smaller diameter.

4. Frequently contains a manageable stand of advanced reproduction.

5. More often clumpy than single- or twostoried stands.

D. Multi-storied stands

1. Generally broad-aged with a wide range in diameters.

2. If the stand developed from a relatively few individuals, overstory trees are coarse limbed, fill-in trees are finer limbed. Overstory trees may be relatively vigorous.

3. If the stand developed from the deterioration of a single- or two-storied stand, overstory may be no limbier than fill-in trees. Much of the vigorous growing stock is below saw log size.

4. Almost always contains a manageable stand of reproduction as a ground story.

5. Fill-in trees may be clumpy, but usually not the overstory.

\section{Cutting Practices}

The form, structure, and arrangement of stands desirable to meet different management objectives suggest certain cutting practices; however, stand conditions, and windfall and insect susceptibility that may vary from place to place on any area, impose limitations on how stands can be handled. Cutting to bring old-growth under management is likely to be a compromise, therefore, between what is desirable and what is possible. Management may involve a combination of several partial cutting treatments, continuous sanitation salvage cutting, clearcutting, and no cutting on many areas. Furthermore, inital cutting will be largely conditioning rather than regeneration cuts.

The following recommendations for the stands described above are suggested as interim guides to initial cutting in old growth, with the objective of maintaining permanent high forest cover to meet the needs of different land uses. ${ }^{5}$ Careful marking of individual trees or groups of trees to be removed, and close supervision of the logging are required: ${ }^{6}$

A. Single-storied stands-These stands are usually the least windfirm because the trees have developed together over a long period of time and mutually protect each other from the wind.

${ }^{5}$ Where mixed stands of spruce, fir, and lodgepole pine occur, pine relative to its position in the canopy, should be handled the same as spruce.

${ }^{6}$ In all stands described where natural openings one to several acres in size occur, leave the trees around the perimeter uncut for a distance of about 1 tree height. These trees have been exposed to the wind and are usually windfirm, and protect the trees in the interior of the stand. 
1. If the windfall risk is below average, and the trees are uniformly spaced, the first cut should be light, removing about 30 percent of the basal area of the stand on an individual tree basis. Since all overstory trees are about equally susceptible to windthrow, the general level of the canopy should be maintained by removing some trees from each overstory crown class. Avoid creating openings in the canopy with a diameter larger than one tree height by distributing the cut over the entire area.

2. If the windfall risk is below average, and the trees are clumpy, the first cut should be a modified group selection that removes about 30 percent of the basal area. Harvesting timber in groups will take advantage of the natural arrangement of trees in clumps. Group openings should be kept small-not more than one to two tree heights in diameter-and not more than one-third of the area should be cutover. However, all trees in a clump should be either cut or left since they mutually support each other, and removing only part of a clump is likely to result in the loss of the remaining trees to windthrow.

3. If the windfall risk is above average, and the trees are uniformly spaced, the first cut should be restricted to a very light intermediate cutting that removes about 10 percent of the basal area on an individual tree basis. The objective is to open up the stand just enough to allow the remaining trees to begin to develop windfirmness. This type of cutting resembles a sanitation cut in that the poorest risk trees (and superdominants) should be removed, but it is important that the general level of the overstory canopy be maintained intact. Provision should be made to salvage windfalls.

4. If the windfall risk is above average and the trees are clumpy, the first cut should be light, removing about 10 to 20 percent of the basal area in a modified group selection. Group openings should be no larger than one

\footnotetext{
${ }^{7}$ As a practical matter, small saplings that do not represent significant competition to the remainder of the stand may be excluded from the computation of basal area.
}

tree height in diameter, and not more that one-fifth of the area should be cut over at any one time. All trees in a clump should be cut or left. In stands with small natural openings-about one tree height in diameter-the openings can be enlarged one tree height by removing clumps of trees to the windward.

5. If the windfall hazard is very high, or the stand is breaking up, the choice is usually limited to removing all the trees or leaving the area uncut.

B. Two- and three-storied stands-Trees in the overstory are usually more windfirm than those in single-storied stands dependent on each other for protection. The second and third stories are likely to be less windfirm than the top story.

1. If the windfall risk is below average, and the trees are uniformly spaced, the first cut can remove up to 40 percent of the basal area. This type of cutting is heavy enough to resemble the first step of a two-cut shelterwood, but the marking follows the rules for individual tree selection-mature trees are removed from each story. Heavier cuts (60 percent or more of the basal area) may be possible in some instances, but the appearance of a continuous overstory canopy may not be retained. Since the overstory is likely to be more windfirm, selected dominants and codominants should be left. Avoid cutting holes larger in diameter than one tree height in the canopy by distributing the cut over the entire area.

2. If the windfall risk is below average, and the trees are clumpy, the first cut should remove about 40 percent of the basal area in a modified group selection cutting. The group openings can be larger (two to three times tree height) than for single-storied stands, but the area cutover should be not more than one-third of the total. Furthermore, the group openings should be irregular in shape but without dangerous wind-catching indentations in the edges. All trees in a clump should either be cut or left.

3. If the windfall risk is above average, and the trees are uniformly spaced, the first cut should be a light intermediate cutting that removes not more than 
20 percent of the basal area, on an individual tree basis. Superdominants and codominants and intermediates with long, dense crowns should be removed first. Maintain the general level of the canopy. Provision should be made to salvage windfalls.

4. If the windfall risk is above average, and the trees are clumpy, the first cut should be a modified group selection that removes 20 to 30 percent of the basal area. Group openings should be kept small-not more than one to two tree heights in diameter-and not more than one-fourth of the area should be cut over at any one time. All trees in a clump should either be cut or left. Small natural openings can be enlarged one to two tree heights by removing trees in clumps to the windward of the opening.

5. If the windfall hazard is very high, or the overstory is breaking up, any partial cutting is a calculated risk.

C. Multi-storied stands-These are usually the most windfirm, even where they have developed from the deterioration of single- and two-storied stands, because by the time they have reached their present condition, the remaining overstory trees are usually windfirm.

1. If the windfall risk is below average, there is considerable flexibility in harvesting these stands. All size classes can be cut with emphasis on either the largest or smallest trees in the stand. For example, the first cut can range from removal of all large trees in the overstory to release the younger growing stock, to a thinning from below to improve the spacing of the larger trees. Thereafter, cutting can be directed toward uneven-aged management.

2. If the windfall risk is above average or very high, the safest first cut is an overwood removal with a thinning from below to obtain a wide-spaced, open-grown stand that will develop windfirmness. Thereafter, cutting should be directed toward even-aged management.

Although regenerating a new stand is not the primary objective of the harvesting practices recommended, and conventional approaches can seldom be used in spruce stands because of limitations imposed by stand conditions and windfall and insect susceptibility, openings made in the canopy by the modified group selection and shelterwood cuttings suggested are large enough to permit new spruce reproduction to become established in significant numbers. Furthermore, a partial overstory canopy or trees standing around the perimeter of small openings provide two of the basic elements needed for regeneration success-a continuing source of seed within effective seeding distance, and an environment compatible with germination and early seedling survival (Roe et al. 1970). To provide the third needed element-a suitable seedbed-it may be necessary to remove heavy accumulations of duff and litter to expose mineral soil, and reduce competition from understory vegetation. Some of the larger pieces of slash and other down material should be left in place to provide shade for new seedlings.

\section{Literature Cited}

Alexander, Robert R.

1957. Damage to advanced reproduction in clearcutting spruce-fir. U. S. Forest Serv., Rocky Mt. Forest and Range Exp. Sta. Res. Note 27, 3 p. Ft. Collins, Colo.

1958. Silvical characteristics of Engelmann spruce. U. S. Forest Serv., Rocky Mt. Forest and Range Exp. Sta. Sta. Pap. 31, 20 p. Ft. Collins, Colo.

1963. Harvest cutting old-growth mountain spruce-fir forests in Colorado. J. Forest. 61: 115-119.

1964. Minimizing windfall around clearcuttings in spruce-fir forests. Forest Sci. 10: 130-142.

1967. Windfall after clearcutting on Fool Creek, Fraser Experimental Forest. U. S. Forest Serv. Res. Note RM-92, 11 p. Rocky Mt. Forest and Range Exp. Sta., Ft. Collins, Colo.

Barnes, R. Lawrence.

1971. Patterned tree harvest proposed. West. Conserv. J. 28: 44-47. 
Hoover, Marvin D., and Charles F. Leaf.

1967. Process and significance of interception in Colorado subalpine forest. Int. Symp. Forest Hydrol. [Pa. State Univ., Aug. - Sept. 1965] Proc. 1965: 213-224. N. Y.: Pergamon Press.

Hopkins, A. D.

1909. Practical information on the scolytid beetles of North American Forests. I. Barkbeetles of the genus Dendroctonus. U. S. Dep. Agr. Bur. Entomol. Bull. 83 , pt. 1, 169 p.

LeBarron, Russell K., and George M. Jemison. 1953. Ecology and silviculture of the Engelmann spruce-subalpine fir type. J. Forest. 51: 349-355.

Martinka, Robert R.

1970. Structural characteristics and ecological relationships of male blue grouse territories in southwestern Montana. Mont. Fed. Aid Job Compil. Rep. Proj. W-91-R-10-12, Job No. 3.1 (II-D) 73 p. Mont. Fish and Game Dep., Helena.

Massey, C. L., and N. D. Wygant.

1954. Biology and control of the Engelmann spruce beetle in Colorado. U. S. Dep. Agr. Circ. 944, 35 p.

Miller, Philip C.

1970. Age distributions of spruce and fir in beetle-killed forests on the White River Plateau, Colorado. Amer. Midl. Natur. 83: 206-212.

Oosting, Henry J., and John F. Reed.

1952. Virgin spruce-fir of the Medicine Bow Mountains. Ecol. Monogr. 22: 69-91.
Reynolds, Hudson G.

1966. Use of openings in spruce-fir forests of Arizona by elk, deer, and cattle. U. S. Forest Serv. Res. Note RM-66, 4 p. Rocky Mt. Forest and Range Exp. Sta., Ft. Collins, Colo.

Roe, Arthur L., Robert R. Alexander, and Milton D. Andrews.

1970. Engelmann spruce regeneration practices in the Rocky Mountains. U. S. Dep. Agr. Forest Serv., Prod. Res. Rep. $115,32 \mathrm{p}$. , and G. M. DeJarnette.

1965. Results of regeneration cutting in a spruce-subalpine fir stand. U. S. Forest Serv. Res. Pap. INT-17, 14 p. Intermt. Forest and Range Exp. Sta., Ogden, Utah.

Schmid, J. M., and Roy C. Beckwith.

1971. The spruce beetle. U. S. Dep. Agr. Forest Pest Leafl. 127, 7 p.

U. S. Forest Service.

1933. Annual report (twenty-third year), Rocky Mountain Forest Experiment Station, Rocky Mountain Region [1932]. Mimeo., $71 \mathrm{p}$.

Wallmo, O. C.

1969. Response of deer to alternate-strip clearcutting of lodgepole pine and spruce-fir timber in Colorado. U.S.D.A. Forest Serv. Res. Note RM-141, 4 p. Rocky Mt. Forest and Range Exp. Sta., Wygant, N. D. Ft. Collins, Colo.

1958. Engelmann spruce beetle control in Colorado. 10th Int. Congr. Entomol. [Montreal, Aug. 1956] Proc. 4: 181-184. 


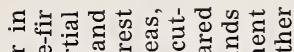

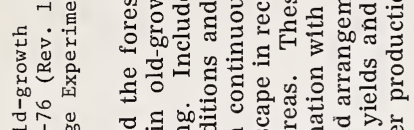

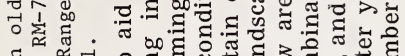

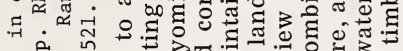

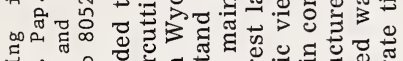

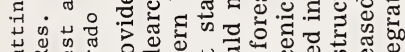

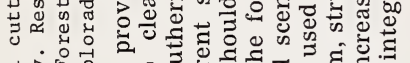

ส

艺

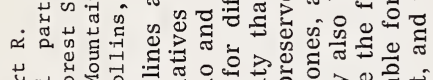

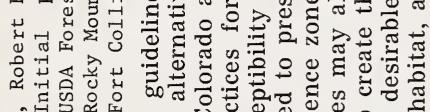

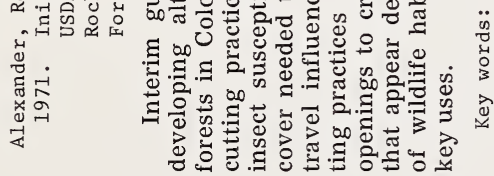

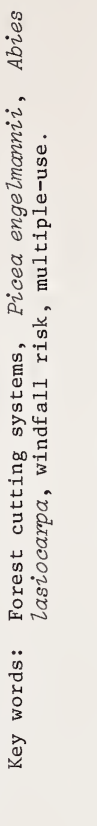

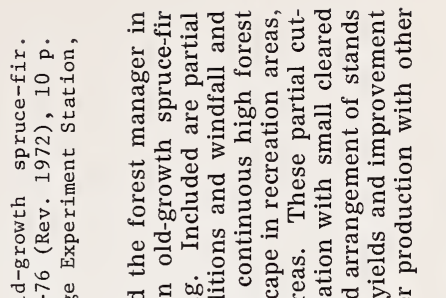

开交品.

.

कि न्षे ट्ष

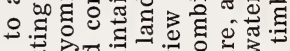

声 $\dot{0}$ के

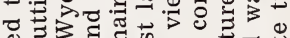

उु 必近

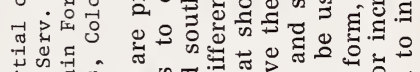

式

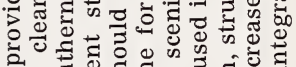

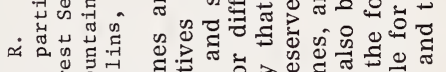

प्रु त्र

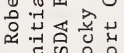

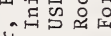

पू山

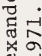

㤩芯

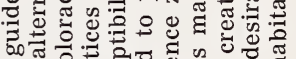

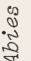

वे

द्य 0000

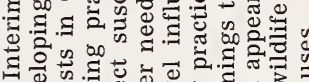

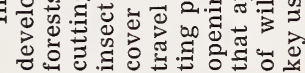

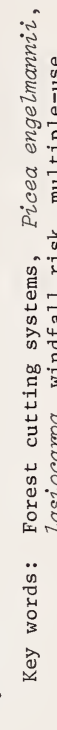

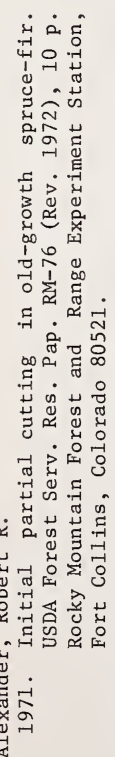

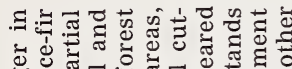

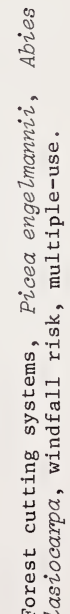

就

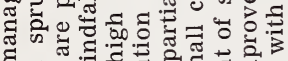

a

ज力

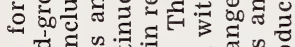

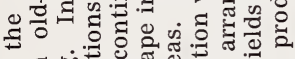

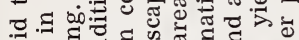

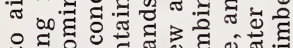

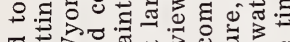

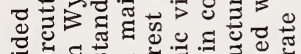

ग

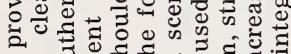

Dᄋ

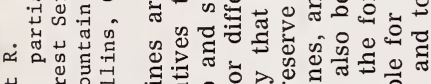

पूँ

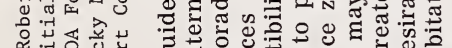

둘

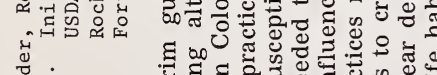

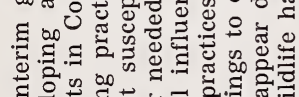

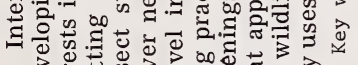

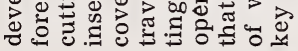

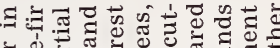

में

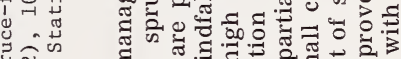

के

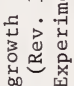

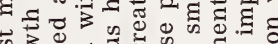

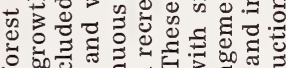

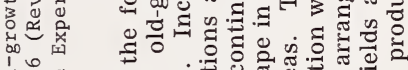

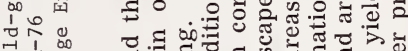

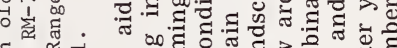

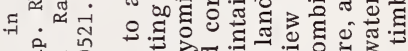

किष चै के

푸

उु选造

ช

ता

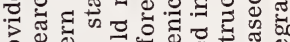

नु द्रु

के

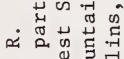

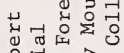

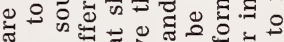

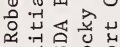

돔요

离

ขै

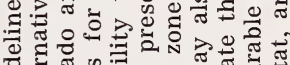

正

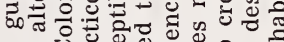

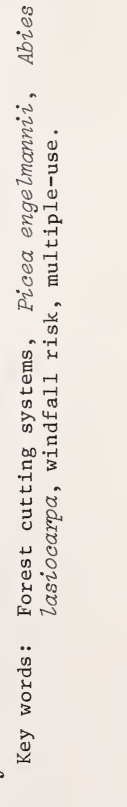




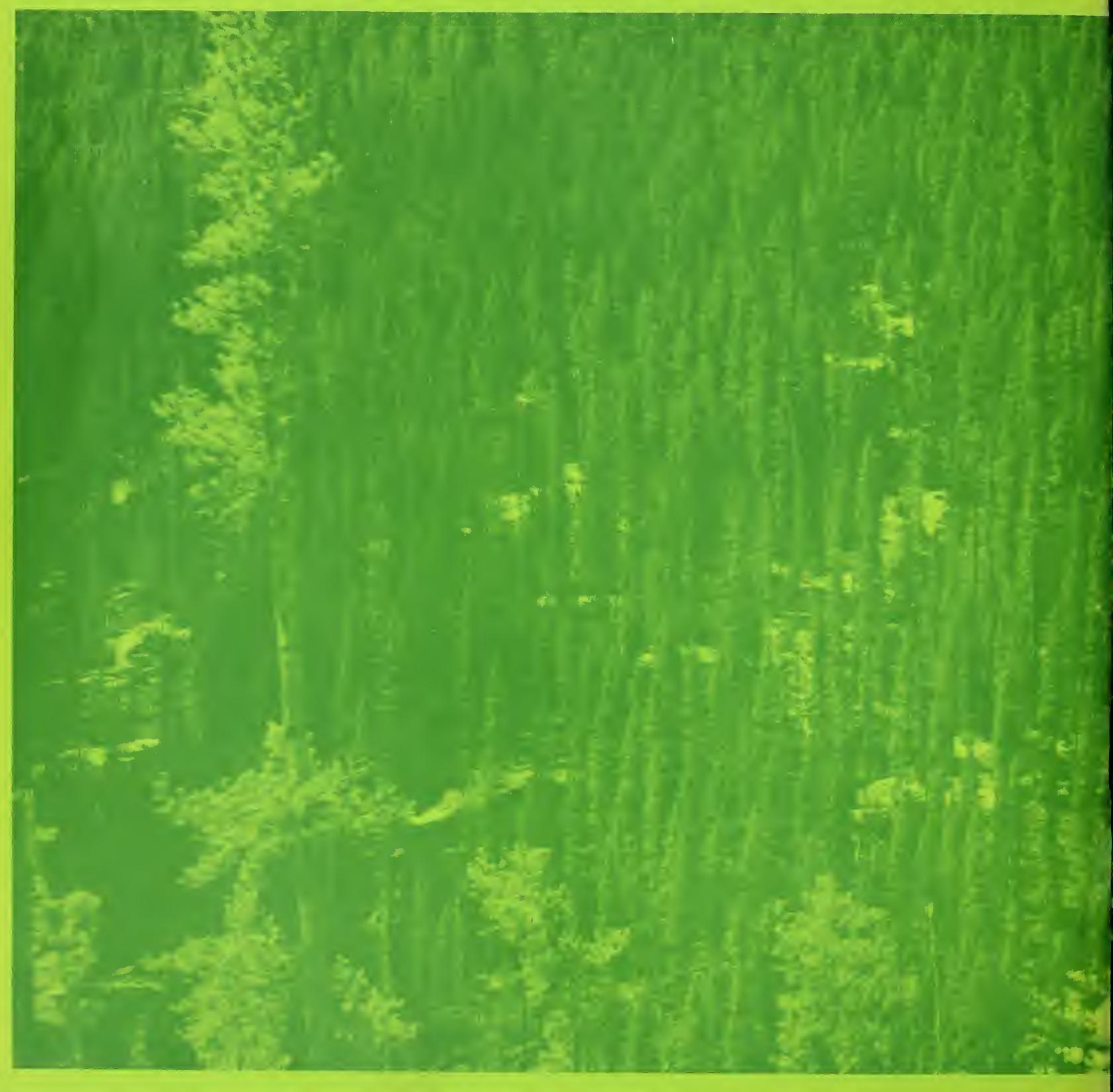

